\title{
Improved harmonization of critical characterization assays across cell therapies
}

\author{
Francis Karanu*,1, Lindsey Ott ${ }^{1}$, Debra Aub Webster ${ }^{2}$ \& Lisa Stehno-Bittel ${ }^{1,3}$ (iD \\ ${ }^{1}$ Likarda, LLC, 10330 Hickman Mills Drive, Kansas City, MO, USA \\ ${ }^{2}$ Cardinal Health Regulatory Sciences, 7400 West 100th Street, Overland Park, KS 66210, USA \\ ${ }^{3}$ Department of Rehabilitation Science, University of Kansas Medical Center, MS 2002, 3901 Rainbow Blvd, Kansas City, KC, USA \\ *Author for correspondence: fkaranu@likarda.com
}

The field of cell therapy has blossomed, providing exciting new options for treating a variety of diseases. While few cell therapy products have US FDA approval, there are thousands of cell treatments at various stages of development, pointing to a potential revolutionary shift in patient care. The expanding number and nature of cellular therapies necessitate greater standardization. Several international organizations are collaborating to pursue some level of global standardization, especially concerning cell banking. However, less harmonization surrounds assays used for critical quality characterization including: identity, purity, safety and potency. Frequently, there is divergence regarding the terms describing the characterization assays across regulatory authorities and guidances. This review summarizes the critical quality assays currently used for different categories of cell therapies. Areas of harmonization and an absence of standardization are highlighted. We propose potential solutions to facilitate harmonization of critical quality characterization assays and the language used to describe them.

First draft submitted: 6 January 2020; Accepted for publication: 3 May 2020; Published online:

26 June 2020

Keywords: cell therapy • embryonic stem cells $\bullet$ hematopoetic stem cells $\bullet$ induced pluripotent stem cells $\bullet$ industry - manufacturing • mesenchymal stromal cells • regulation

Regenerative medicine is an exciting and rapidly developing treatment arena. Yet, only recently has the larger regenerative medicine industry matured to provide cell therapies directed at a variety of indications. In doing so, the field is moving from a clinical manufacturing model, generally occurring in select academic institutions, to an industry model with centralized manufacturing [1]. Currently, the US FDA lists 14 approved cellular therapy products [2]. Half of these are allogeneic umbilical cord blood hematopoietic progenitor cells (HPC). For allogeneic HPC cord blood, the FDA has provided guidance documents setting out the criteria for manufacturing, including the purity, potency and identity criteria [3].

The remaining cellular therapies are indicated for a variety of disorders including lymphoma, prostate cancer, cartilage defects and cosmetic applications. While only 14 products have been approved, there are currently numerous active human clinical trials using cell therapies. In 2020, Clinicaltrials.gov listed over 1800 active/recruiting clinical trials utilizing some type of stem cell collection or therapy [4]. The FDA has provided numerous Guidance for Industry documents with respect to developing therapies based on human cells. However, with the plethora of cell therapies under investigation, the field could benefit from a more defined approach such as that taken by the FDA in the case of allogeneic HPC cord blood [3].

Many reviews have focused on the challenges of cell therapy manufacturing including the need for closed automated systems that can scale and the innate variability of the cellular starting material, which hampers standardization [5-9]. Several international organizations have worked diligently to create standardization and global harmonization in the field of regenerative medicine. Many of those groups have focused on cell banking. Work by the International Stem Cell Banking Initiative resulted in numerous publications on scientific consensus on topics of expansion, storage and characterization of pluripotent stem cells [10]. In addition, an international consortium established the Minimum Information About a Cellular Assay for Regenerative Medicine in 2016 for cell banks and 
Table 1. Examples of discrepancies in critical quality assays for cell therapies.

\begin{tabular}{|c|c|c|c|}
\hline HPC cell assay categories [5] & Recommended assays & Somatic cell assay categories [14] & Recommended assays \\
\hline \multirow[t]{3}{*}{ Safety } & Infectious diseases & \multirow[t]{3}{*}{ Microbial testing } & Adventitious agent testing \\
\hline & Sterility & & Sterility \\
\hline & Hemoglobin & & Mycoplasma \\
\hline \multirow{2}{*}{ Purity and potency } & Viable nucleated cells & \multirow{2}{*}{ Purity } & \multirow[t]{2}{*}{ Pyrogenicity/endotoxin } \\
\hline & Viable CD34+ cells & & \\
\hline \multirow{2}{*}{ Identity } & Confirmatory HLA typing & \multirow{2}{*}{ Identity } & \multirow{2}{*}{$\begin{array}{l}\text { Distinguish the product from others } \\
\text { manufactured in the same facility using } \\
\text { surface markers or genetic polymorphisms }\end{array}$} \\
\hline & Blood group and Rh Type & & \\
\hline \multirow[t]{2}{*}{ Other } & \multirow[t]{2}{*}{ None } & \multirow[t]{2}{*}{ Other } & Viability \\
\hline & & & Cell number/dose \\
\hline
\end{tabular}

registries [11]. It provides and exhaustive list of cell characterizations for cell banking with the goal of standardizing the data collected on cell lines, but it does not provide guidelines for characterization assays for product release.

Less attention has been placed on the assays used to characterize the quality of either the starting materials or the final product [12]. When comparing FDA guidances for somatic cell therapies versus multipotent stromal cell (MSCs), there are discrepancies between the organizational structure and recommended product tests $[3,13]$. Table 1 illustrates the confusion. The first two columns provide the categories of recommended critical quality assays for HPCs, which are multipotent cells. The last two columns provide the same information provided by the FDA for somatic cell therapies (unipotent cells). While the HPC guidance is more detailed in the recommended assays compared with a general guidance for somatic cells, still it is clear that the same tests are listed in different classifications between the two guidances. For example, viability of HPCs is listed under the category of 'Purity and potency' [3], but the same tests are listed in the 'Other' category for somatic cell therapies [13]. A comparison of information provided in Table 1 uncovers a variety of discrepancies including different titles for the general categories such as safety or microbial testing. The guidance for somatic cell therapies has a separate category for potency tests, while the HPC documents include potency with purity assays. The goal of this review is to compare the current critical quality characterization assays across different categories of cell therapies, highlighting areas of inconsistency and potential for further harmonization. We conclude by suggesting simple alignments across categories for consideration in the context of efforts underway by standard coordinating bodies.

\section{Cell therapy categories}

Cell therapies and cell therapy products can be grouped into three distinct categories based on the starting cell source or material: pluripotent stem cells (embryonic or induced), multipotent (somatic or adult) cells and terminallydifferentiated unipotent cell products. Figure 1 provides a simplified hierarchical organization of the various cell sources based on the development potential of the cell, illustrating the relationship of these cell categories to each other. Table 2 summarizes the three categories, listing the general characteristics and providing examples of approved applications for each group.

Pluripotent stem cells include both embryonic stem cells (ESCs) and induced pluripotent stem cells (iPSCs). Embryonic stem cells are derived from blastocysts, are indefinitely self-renewing and can differentiate into unlimited types of cells. iPSCs are artificially derived cells from adult, differentiated somatic cells that start out as nonpluripotent and are reprogrammed into a pluripotent state. Reprogramming protocols convert the differentiated cells back into embryonic-like states (Figure 1, red arrows) from which they can then progress down any specific lineage, similar to the embryonic stem cells. The figure illustrates this reprogramming for the mesodermal lineage with red arrows, but ectodermal and endodermal cells can be similarly reprogrammed. Figure 1 illustrates that both ESC and iPSC have an inherent ability to produce differentiated cells from any of the three germ layers, dependent upon their external cues in the environment. 


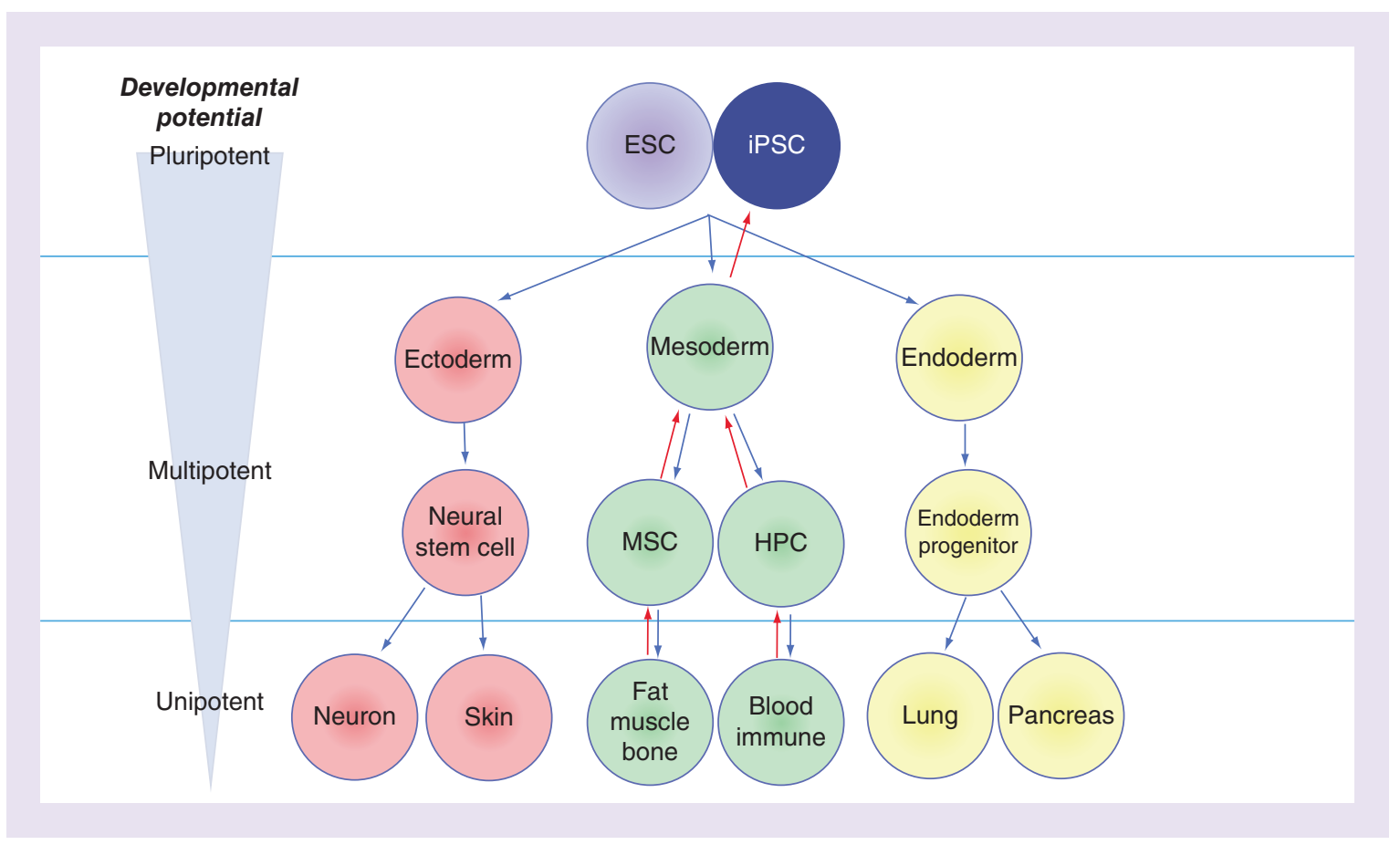

Figure 1. Stem cell differentiation pathways. The capacity of ESCs to differentiate into somatic cells relies on committed pathways via specific somatic lineages (mesoderm, endoderm or ectoderm). Multipotency and replicative potential decline with increased commitment. The blue line represents the ability of ESCs to differentiate into cells of any of the three lineages. The red arrows illustrate a typical pathway for creating an iPSC from somatic tissues.

ESC: Embryonic stem cell; HPC: Hematopoietic progenitor cells; iPSC: Induced pluripotent stem cell; MSC: Multipotent stromal cells.

Table 2. Cell therapy categories.

\begin{tabular}{|c|c|c|c|c|c|}
\hline Category & General characteristics & Starting material & Challenges & Approved therapies & Ref. \\
\hline $\begin{array}{l}\text { Pluripotent stem } \\
\text { cells }\end{array}$ & $\begin{array}{l}\text { Self-renewing and } \\
\text { pluripotent }\end{array}$ & $\begin{array}{l}\text { iPSC is derived from a somatic } \\
\text { cell. } \\
\text { ESC from blastocysts }\end{array}$ & $\begin{array}{l}\text { Cells must be differentiated prior } \\
\text { to transplant. } \\
\text { Potential for tumorgenicity }\end{array}$ & $\begin{array}{l}\text { No current approved } \\
\text { therapies }\end{array}$ & {$[2,12,15]$} \\
\hline $\begin{array}{l}\text { Multipotent stem } \\
\text { cells }\end{array}$ & $\begin{array}{l}\text { Limited self-renewal, } \\
\text { multipotent }\end{array}$ & $\begin{array}{l}\text { Adipose, amniotic tissue, } \\
\text { bone marrow, hematopoietic }\end{array}$ & $\begin{array}{l}\text { Limited renewal hampers } \\
\text { expansion of cells for transplant. } \\
\text { May be transplanted as stem cell } \\
\text { or differentiated. Lower } \\
\text { potential for tumorgenicity. }\end{array}$ & $\begin{array}{l}\text { Hematopoietic stem cell } \\
\text { transplants }\end{array}$ & {$[2,5,12,16]$} \\
\hline Unipotent cells & $\begin{array}{l}\text { Terminally differentiated, } \\
\text { not self-renewing or } \\
\text { multipotent }\end{array}$ & $\begin{array}{l}\text { Dependent on the cell } \\
\text { therapy }\end{array}$ & $\begin{array}{l}\text { Source must have significant } \\
\text { volume of cells because of lack of } \\
\text { expansion capability, unless } \\
\text { genetically modified }\end{array}$ & $\begin{array}{l}\text { CAR-T therapy, autogeneic } \\
\text { islet transplants, } \\
\text { fibroblasts, chrondrocytes } \\
\text { on a membrane }\end{array}$ & {$[2,17,18]$} \\
\hline
\end{tabular}

The three categories of cell therapies, pluripotent, multipotent and unipotent cells, are described including their general characteristics and the starting material from which they arise. The current major challenges are provided along with approved therapies in each category, when appropriate.

CART-T: Chimeric antigen receptor T-cell therapy; ESC: Embryonic stem cell; iPSC: Induced pluripotent stem cell.

While there are no FDA-approved ESC or iPSC treatments have FDA approval, as of early 2020 there were 43 active human clinical trials summarized on Clinicaltrials.gov using ESCs, which is seven-times more than were listed in 2018 [4]. While the same site lists over 90 clinical trials using iPSCs, the majority are limited to tissue collection with only seven trials appearing to utilize iPSCs for treatment of a disorder [4]. Of the three cell categories (pluripotent, multipotent and unipotent), a significant amount of work has been done to regulate and standardize the characterization of pluripotent stem cells (PSCs) [15].

Multipotent stem cells are another category of stem cells found in most tissues from the body. These cells comprise some stem cell properties but differ from pluripotent cells in that they have a limited ability to renew. Typically, these cells can be differentiated only into cells within their lineage (Figure 1), giving rise to the term 
multipotent. Similar to pluripotent cells, differentiation of multipotent stem cells is dependent upon external cues in the environment.

While there are many clinical trials utilizing multipotent cells, currently only HPC transplants are approved by the FDA for patient treatment [3]. As shown in Figure 1, these cells arise from the mesoderm lineage and can produce any of the mature functional hematopoietic cells of the body, including the immune system. Autologous HPC transplants are often used to rescue the hematopoietic toxicity of high dose chemotherapies for patients with blood cancers [16], making them the most common applications for multipotent cells [19].

MSCs, first called mesenchymal stem cells [20,21], are another category of multipotent cells. They are widely popular for research and clinical trials, partly because the tissues from which MSCs are isolated are easily retrieved and are most frequently autologous, with the exception of those derived from amniotic tissues [22]. MSCs have been derived from a long list of tissues including lung, fallopian tube, fetal liver, amniotic tissues, umbilical cord, fat, skin, muscle, liver and dental tissue. By definition, MSCs can be differentiated into three terminal cell types: osteogenic, adipogenic and chondrogenic, but, like all multipotent cells, they have limited self-renewal capabilities. Typically, they lose the ability to differentiate at about 5-12 passages in vitro [23]. In 2020, there were over 1000 human clinical trials listed on Clinicaltrials.gov, using the term mesenchymal stem cells or mesenchymal stromal cells, with most therapeutic applications utilizing autologous tissue harvested from fat or bone marrow and more recently allogeneic MSCs isolated from amniotic tissues [4].

Unipotent cells are terminally differentiated cells that have limited renewal properties or developmental potential (Figure 1). A high number of unipotent cell therapies are currently in different stages of development. For regulatory purposes the FDA excludes blood transfusions from their definition of somatic cell therapies [17,24]. Rather, the FDA regulates the safety of blood through current good tissue practice [17].

Other types of unipotent cell therapies include the transplantation of islets, the insulin-producing clusters of cells taken from the pancreas. Islet transplants have been used to treat severe Type 1 diabetes for 20 years. While considered standard of care in other countries, allogeneic islets transplants are still classified as experimental in the US and patients can only receive them by enrolling in a clinical trial [25]. However, autologous islet transplants for the treatment of conditions such as pancreatitis are approved and covered by private insurance in the US (Table 2).

Some unipotent cell therapies involve genetic modification, such as therapies utilizing chimeric antigen receptor $\mathrm{T}$-cells (CAR-T), which are autologous, genetically-modified $\mathrm{T}$ cells. The genetic modification optimizes the $\mathrm{T}$ cells to actively proliferate and recognize cancer cells. This is an extremely active field of study with two approved CD19directed CAR-T-cell treatments as of 2020 and over 2500 current clinical trials for genetically modified cellular therapies for a variety of indications [4]. Additional examples of unipotent cell transplants include lymphocyte infusions to treat relapsed leukemia [26] and mature dendritic cells to assist in abating solid organ transplant rejection [27].

Each type of cell therapy has unique challenges, but a consistent hurdle that must be overcome is the reproducible manufacturing and testing of the cell therapy product. Autologously derived cells are inherently variable, reflecting the age, health status and genetic makeup of the donor, making the characterization of the starting material more challenging than traditional biologics [28]. Additionally, cells are not inert materials; rather they change over time and in response to external signals [29]. Given this inherent variation, valid release testing and product characterization is essential to ensure consistency in cell therapy manufacturing.

\section{Critical quality attributes $\&$ their assays across cell therapies}

The critical quality attributes that allow for the release of a cell therapy are specified in the US Code of Federal Regulations (21CFR610) as sterility, purity, identity and potency. As discussed previously, other regulations do not use the same organizational structure. For example, safety, sterility, purity and potency, but not identity, are defined in 21CFR600.3 [30]. In 21CFR600.3(p) safety is defined as "relative freedom from harmful effect to persons affected, directly or indirectly, by a product when prudently administered, taking into consideration the character of the product in relation to the condition of the recipient at the time". Thus, while the HPC Guidance uses the term 'safety' to describe the testing of infectious diseases and sterility, safety should encompass a broader set of tests for quality, nonclinical and clinical testing. In fact, safety is captured in all of the critical quality attributes of the cellular product.

The FDA has issued several guidelines describing how the agency interprets these definitions with respect to critical quality attributes needed for release of cell-based therapies [30-32]. Sponsors developing a cellular therapy must provide data supporting the assays used to accurately and reproducibly confirm: the cellular identification of the final product, the preparation purity, sterility and potency [31]. The schematic in Figure 2 organizes these 


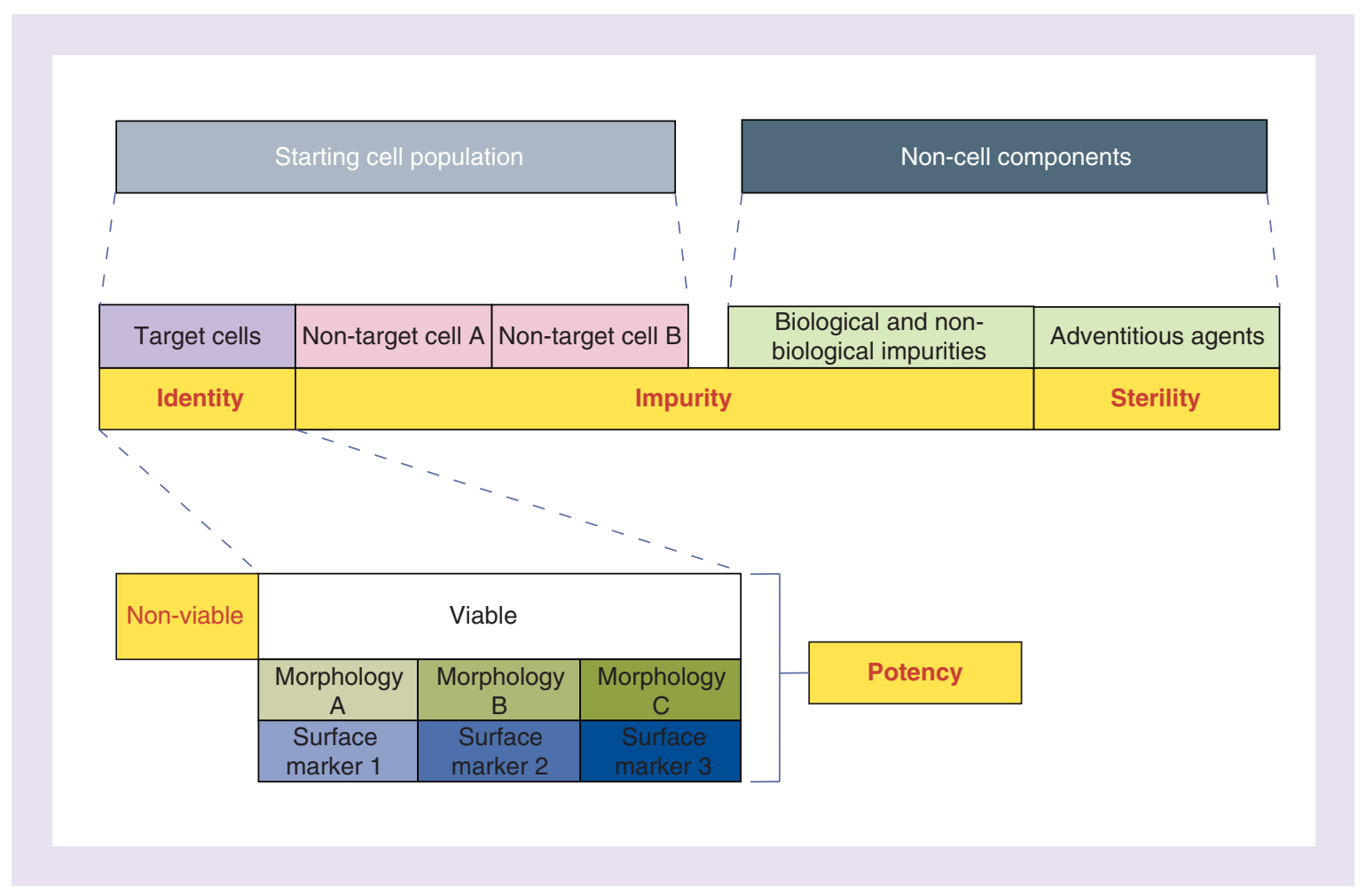

Figure 2. Organization of critical characterization assays. Cell therapies contain noncellular components and a cellular population. Testing of the target cellular component determines the identity and the cellular purity of the preparation. Assays focused on the noncellular components test for impurities. Components that include adventitious agents are considered part of the sterility assessment. Characterization of the target cellular component can define the potency of the product including assays for viability, cell number and the assumed mechanism of action.

four critical quality attributes based on a format suggested by authors from the National Institute of Standards and Technology [33]. We have adapted their framework which describes the composition of a cellular preparation and organized it according to identity, impurity, sterility and potency testing.

The characterization process begins with a starting cell population comprised of the target cells along with other nontarget cells (Figure 2). The 'Identity' of the preparation is determined by quantitative testing (phenotypic or biochemical assay) to confirm that the target cells are present in the product. Characterizing the nontarget cells is required for assessing the 'impurity' attributes of the preparation. This includes identifying and quantifying other extraneous matter, including biological and potential nonbiological impurities such as reagents. In practical terms purity and identity are often provided in a single heading due to their overlapping assays and results [33]. By clarifying identify as the description of the target cells and impurity as identification of nontarget materials and cells, better harmonization across cell therapies can be achieved. Similarly, unwanted microorganisms affect the 'sterility' of the product, resulting in a critical characteristic with respect to safety. Finally, the target cells must be tested for 'potency'. Viability should be considered a critical potency assay for all cell therapies along with the cell number and individual tests based on the assumed mechanism of action. The schematic in Figure 2 creates a common approach and language for all cell therapies.

While the schematic may seem well defined, a lack of clarity and common definitions still creates confusion. For example, several characterization assays are placed under multiple headings of identity, purity, sterility and potency. For instance, an assay focused on the safety concern of endotoxins is listed as a purity attribute in some FDA guidances [32], while bacterial testing is listed under sterility. Given the fact that endotoxins are products of bacteria, it would be more informative and appropriate to include both under the same category.

Development of an assay for assessment of critical quality attributes is a progressive, iterative process. A better understanding of these terms and definitions and their application in the development of cellular therapies will lead to more efficient delineation of critical quality attributes needed for product release and licensure, providing 
Table 3. Current cell identity assays.

\begin{tabular}{|c|c|c|c|c|}
\hline Characterization & Pluripotent stem cells & Multipotent stem cells & Unipotent cells & Ref. \\
\hline Molecular markers & STR genotyping & & & [35-37] \\
\hline $\begin{array}{l}\text { Surface markers (starting } \\
\text { material) }\end{array}$ & $\begin{array}{l}\text { SSEA-3, SSEA-4, TRA-1-60, } \\
\text { TRA-1-81, } \\
\text { Nanog, SOX-2, OCT-4 }\end{array}$ & 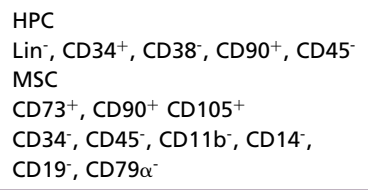 & $\begin{array}{l}\text { Cell-specific, but typically surface } \\
\text { markers tested using flow } \\
\text { cytometry }\end{array}$ & [36-43] \\
\hline Phenotypic markers & $\begin{array}{l}\text { Colony formation } \\
\text { (number, density and quality) } \\
\text { EB formation with detection of } \\
\text { trilineage (mesoderm, ectoderm, } \\
\text { endoderm) }\end{array}$ & $\begin{array}{l}\text { Colony formation } \\
\text { Adherence to plastic } \\
\text { Differentiation into adipocytes, } \\
\text { chondrocytes and osteogenesis }\end{array}$ & Microscopic identification & [42-44] \\
\hline Cellular morphological & Nuclear/cytoplasmic area & General morphology & General morphology & [45] \\
\hline Teratoma & Negative & Negative & Not required & [46] \\
\hline Karyotype analysis & $46, X X$ or $X Y$ & $46, X X$ or $X Y$ & Not required & {$[47,48]$} \\
\hline Other tests & $\begin{array}{l}\text { ALP staining } \\
\text { Genome-wide gene expression } \\
\text { pattern should match the donor }\end{array}$ & $\begin{array}{l}\text { SA- } \beta-\text { Gal } \\
\text { SRC assay (in vivo) } \\
\text { LTC-IC }\end{array}$ & Not required & [49] \\
\hline
\end{tabular}

a clearer approach to the design and implementation of characterization assays. Below, we review the four critical quality attributes in more details for each category of cell therapy.

\section{Identity}

Assays to determine identity are used to confirm that the product contains the intended cellular and noncellular components and are a part of the critical quality attribute for the product [12]. The FDA does not define identity, but only specifies that identity must be established. It is up to the sponsor to provide the method of identification, whether it is through morphological features, chemical characteristics or in vivo tests [14]. These assays are essential for testing the starting material and equally important for the final product because cells can undergo changes during the manufacturing process. While the concepts of identity and purity are fairly straightforward when the drug is a chemical entity or protein, they become extremely complicated when the 'drug' is composed of cells containing thousands of different proteins, lipids and nucleic acids in addition to multiple cell types [34]. Further, each cell is slightly different, even when the starting material is banked ESCs. Assays for cellular identity are some of the most disparate between the different types of cell therapies and are summarized in Table 3.

\section{Pluripotent stem cells}

The identity of the starting material or master cells used for PSC therapies must be established and carefully monitored over time. Significant work in this arena has been undertaken by other organizations regarding identity assessments [15,29]. In fact, across the world there is wide acceptance of the identity criteria for PSCs and they will briefly be summarized here as other reviews provide more detail on the topic [15,50].

Because of the inherent risk of transformation of the cells during expansion and manufacturing, the genetic identity of the cells compared with the starting material is essential. The International Stem Cell Banking Initiative provided critical steps to characterize iPSCs. This group concluded that short tandem repeats (STRs) should be a mandatory assay for identity and that the acceptance criteria should be an identical match of STRs with the original cell source (Table 3) [51]. STRs are 1-6 base pair repeated DNA sequences that have a high mutation rate that can be affected by cell population doubling and the sex and the age of the donor [51]. The exact STRs that should be included in testing has been standardized by the US Federal Bureau of Investigation [35]. The objective of STR genotyping of pluripotent cells is to demonstrate that the STRs for an iPSC line or later passages of ESCs are identical to those of the starting cells $[36,37,51]$.

Chromosomal aberrations for ESCs and iPSCs are a hallmark of human cancer due to potential genetic instability [47]. Thus, part of identity testing involves knowledge of the genetic stability of the cells. Karyotyping via 

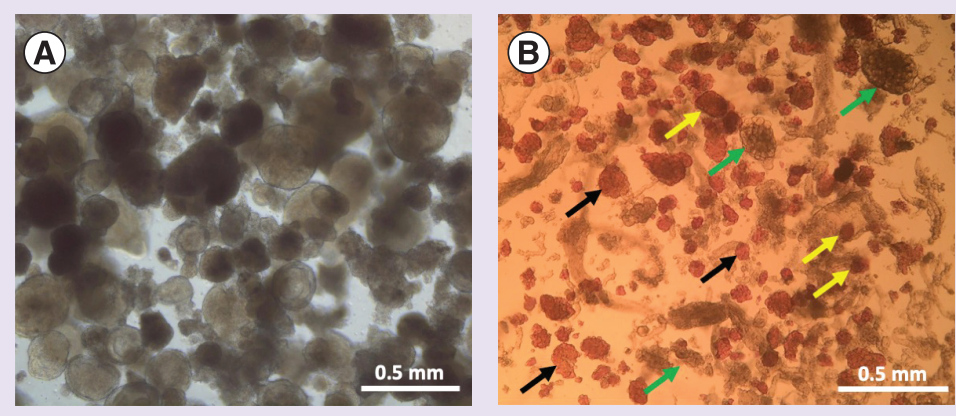

Figure 3. Examples of ambiguity inherent in some morphology assays. Often the quantification of image-based assays can introduce subjectivity into the assay. (A) Embryoid body-like cell clusters formed from differentiated human induced pluripotent stem cells develop in a variety of sizes and shapes and often bind together, making the counting and measuring of the embryoid body-like clusters unclear. (B) The assay to identify endocrine from exocrine somatic cells for islet transplants uses dithizone to stain islet cells red (black arrows highlight some examples) and nonislet cells are left a brown shade (green arrows). However, there are many cell clusters that are ambiguous in their color. Examples are illustrated with yellow arrows.

G-banding detects gross chromosomal duplications, deletions or translocations [47]. The International Stem Cell Banking Initiative Guidelines for release testing of banked cell lines suggest counting at least 20 metaphase spreads with greater than $95 \%$ of the cells determined to be of normal karyotype [48]. As Table 3 shows, identification of 46 chromosomes with either XX or XY is essential.

Identity for the starting ESC or iPSCs also includes assessment of membrane-bound surface markers. The major surface markers are identical for iPSC and ESC and include SSEA-3 and SSEA-4, which are canonical cell surface markers and tumor recognition antigens TRA-1-60 and TRA-1-81 [38] along with self-renewal genes such as Nanog and SOX2 (Table 3) [39,40]. While individual product specifications are different, most manufacturing sites use a $70 \%$ cut-off for major surface markers for rejection of a batch, meaning that at least $70 \%$ of the cells should be positive for these markers [12,36,37]. Upon differentiation for the end product, the pluripotent markers decrease in expression levels. Thus, the final product will have a very different surface marker profile than the starting material. For example, differentiated cardiomyocytes require the inclusion of muscle-specific genes or proteins like those associated with sarcomeres, gap junctions and ion channels [52]. It is important to remember that even fully differentiated cells may hold some epigenetic memory of their initial source [53] and can dedifferentiate at points in the manufacturing process or postrelease.

The level of ALP is another marker of stem cells because they have high levels and high activity of ALP. As pluripotent stem cells become committed to a lineage, ALP expression downregulates and it only appears in discrete specialized somatic cells [49], for example, in osteoblasts.

Phenotypic or morphological assessments are essential for identifying the master pluripotent cells. Although not automated and somewhat subjective, these manual assessments are still considered standard procedures. Embryoid body formation is commonly used to verify the pluripotency of human ESC and iPSCs (Table 3) [51]. Colonies are graded based on colony number, density and quality [54]. Figure 3A provides another example of the complexity when attempting to characterized EB (embryoid body)-like cell clusters differentiated from pluripotent cells. The figure shows differentiated human iPSCs cultured in suspension that form EB-like clusters. The extreme variability in size and shape makes grading the EB-like clusters based on number, size and quality prone to inaccuracies. Other cellular morphological assessments are quite common [45]. One example consists of measuring the ratio of nuclear area to cytoplasmic area, which is typically high in pluripotent cells [47].

\section{Multipotent stem cells}

The identity of the source material for multipotent cells is significantly more complex than for pluripotent cells. By nature, the starting material for multipotent cells is human tissue, which is a heterogeneous mix of cells and support matrices. Those working in the hematopoietic cell field have established unique in vivo and in vitro assays to test HPC identity and functional activity. One in vivo assay first described in 1997 is the severe-combined immunodeficiency mouse-repopulating cells assay. The test identifies cells capable of repopulation in conditioned 
immunodeficient mice (Table 3) [46]. Alternatively, the long-term culture-initiating cell assay, is an in vitro assay comprised of culturing cells on bone marrow feeder cells to determine the capability of the stem cells to produce mature hematopoietic cells [55]. Unfortunately, both assays are lengthy, making them difficult to implement in real time release testing. For example, the long-term culture-initiating cell test can require 6 weeks or longer.

Surface markers for HPC identity include $\mathrm{CD} 34^{+}, \mathrm{CD} 38^{-}, \mathrm{CD} 90^{+}$and $\mathrm{CD} 45^{-}$as defined by the International Society for Cellular Therapy [41,56]. In contrast, multipotent stromal cells have at least 42 different surface proteins that could be used for identification [42]. The International Society for Cellular Therapy suggests that the positive cell markers (CD73, CD90 and CD105) should be expressed in $>95 \%$ of the MSCs in the sample and the cells should be negative for CD34, CD45, CD11b, CD14, CD19 and CD79 $\alpha$ (Table 3) [56]. Other groups have suggested labeling for different proteins including STRO-1, CD271, SSEA-4 and CD146 to identify MSCs [42,43]. This has led some experts in the field to suggest that the surface antigens for MSCs are dependent on the starting cell source and therefore a single set of surface markers cannot be used to identify the category of multipotent cells $[42,57]$.

To highlight the disparity of markers in the multipotent cell category, a review of investigational new drug (IND) applications at the FDA revealed that many companies are not using the International Society for Cellular Therapy Guidance. In 66 different INDs, a lack of CD45 expression was the most commonly used indicative surface marker, followed by $\mathrm{CD}_{105^{+}}$and $\mathrm{CD} 90^{+}$. The remaining surface markers were only utilized in approximately half of the applications, while other markers such as CD29, CD106 and CD80 were used in about a quarter of the applications [58]. The review of FDA INDs provides a window into the great variability in the manufacturing and characterization of cell therapy products.

Further identification by the International Society for Cellular Therapy identifies MSCs by their ability to adhere to plastic. However, only a fraction of the plastic-adhering cells exhibits multipotency [43]. Another test of identity is the trilineage test; the ability to differentiate into chondrocytes, osteocytes and adipocytes [42,43]. Unfortunately, there is great variation in the differentiation protocols used around the world, which can influence the outcome of the test [42]. In addition, it is thought that only a small percentage of cells within the culture can differentiate into specific lineages; cells that are more likely to produce adipocytes are less likely to differentiate into osteocytes and vice versa [59].

Like their pluripotent relatives, multipotent cells should be assessed for phenotypic characterization. Early in the manufacturing process, multipotent cells have the ability to form colonies [44], much like pluripotent stem cells. Colony formation is a very crude estimate of the MSC titer, but a routinely accepted standard for identity [42].

Finally, MSCs have the unique disadvantage in that they cannot be passaged in an unlimited fashion such as ESCs [23] but are still susceptible to chromosomal aberrations with passaging. Thus, karyotyping should be performed, similar to PSCs [6]. While the antigen markers discussed above have been shown to be preserved through multiple rounds of passage in culture, the phenotype of the cells clearly changes. The standard assay for MSC senescence is expression of SA- $\beta-$ Gal [60].

\section{Unipotent cells}

The concept of cell identity for somatic cell therapies is itself complicated. For example, matrix-induced autologous chondrocyte implantation (MACI) is an approved treatment for lesions of the articular cartilage utilizing the patient's own cells in an engineered matrix. Current manufacturing of MACI utilizes genetic markers to identify the chondrocytes in the product. Comparisons with other tissue engineered-products shows great variability between the final products, partly due to the inherent variability in the starting material [61].

When the final product is a heterogeneous cell cluster such as pancreatic islets, additional challenges occur. Identity assessment in these cases tend to be more subjective. For example, the standard test to determine insulinproducing $\beta$-cells within islets is a subjective colorimetric assay, based on the $\mathrm{Zn}$-binding probe, dithizone. The insulin producing $\beta$-cells have a higher $Z n$ content than surrounding cells and thus stain a red color when exposed to dithizone, as shown in Figure 3B. The image shows a preparation with a high level of dithizone-positive cell clusters (red) compared with the darker brown nonislet tissue. Black arrows identity examples of the dithizone-positive cells and green arrows distinguish the nonislet clusters. However, there are cell clusters that are ambiguous (yellow arrows) and whether they are identified as islet or not, is subjective. Differentiating between the islet and nonislet tissue using dithizone staining is tedious and extremely subjective, leading to high intratechnician reproducibility with a coefficient of variance of up to $16 \%$ [62]. 


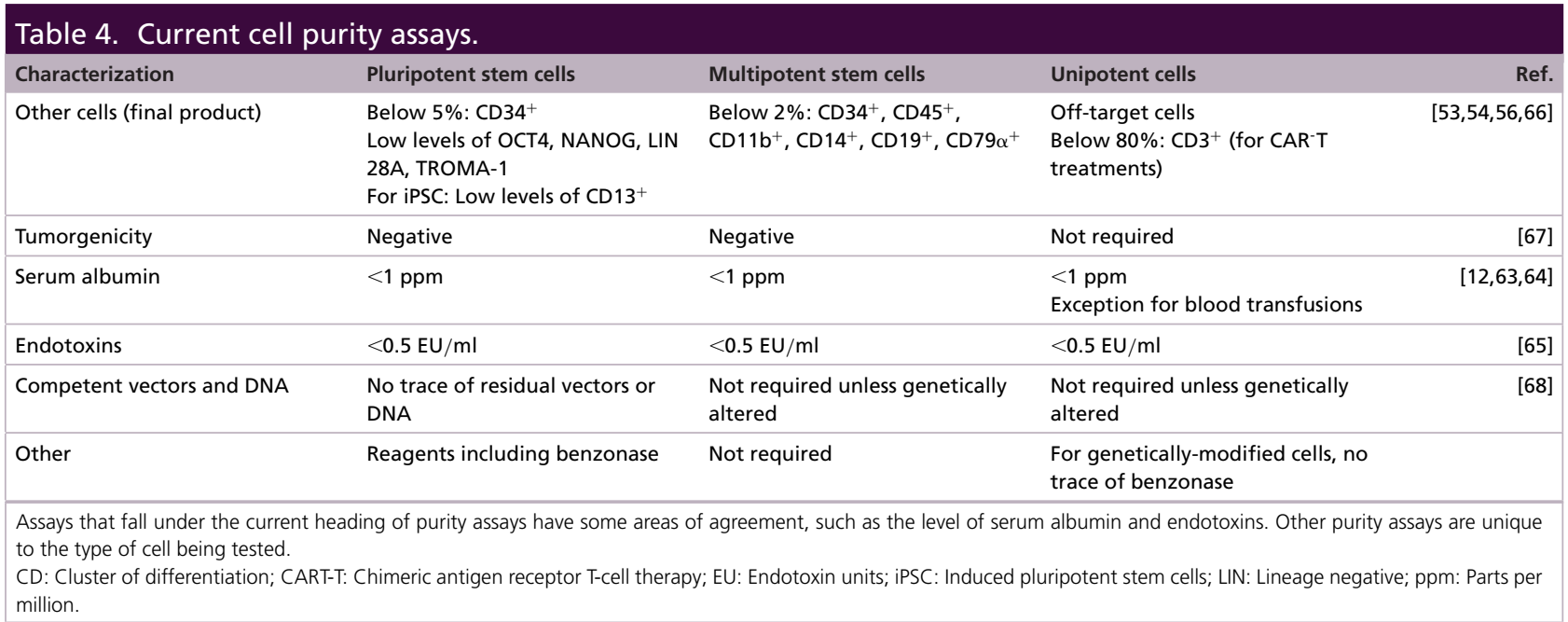

\section{Purity}

For almost every cell therapy, there will be a purification step in the manufacturing process, utilizing methods such as fluorescently- or magnetically-activated cell sorting, metabolic selection or density gradient separation along with other less common methods [48]. It is important to assess any impurities that may result from these manufacturing steps, such as the potential for introduction of adventitious agents and residual beads. Additionally, it is unlikely that the final product will contain a single pure cell type, meaning that the nontarget cells included in the product should be considered impurities and may represent a potential safety risk (Figure 2) [12]. The 21CFR600.3 defines purity as "the relative freedom from extraneous matter in the finished product, whether or not harmful to the recipient or deleterious to the product" [30]. In current regulatory documents, impurities are varied and include endotoxins, residual proteins, vectors or DNA, along with contaminating cells or culture reagents such as fetal bovine serum.

For some of the characterization assays under the heading of purity, there is wide agreement on the assay outcome. Culturing cells with animal serum is still common in cell manufacturing and often is essential for some cells to survive, although new animal serum-free supplements have shown promise [12,63,64]. Federal regulations determine that the animal serum is an impurity and levels must be below $1 \mathrm{ppm}$ in the final product, no matter the type of cell therapy (Table 4). In addition, endotoxin levels must be below $0.5 \mathrm{EU} / \mathrm{ml}$ for the final product to be released regardless of the cell category [65].

\section{Pluripotent stem cells}

While most surface markers for iPSCs and ESCs are used for positive identification, unwanted cells in the final products can be ruled out using the same surface markers. For the starting material, it is common to set expression of unwanted $\mathrm{CD}_{3} 4^{+}$cells at levels below $5 \%$ of the cell population to qualify (Table 4) [53]. Other surface markers can be used to identify nontarget cells such as endoderm and trophoblast cells. One of the most common is TROMA-1 which is directed against cytokeratin-like filaments of trophectoderm and endoderm cells [54]. For iPSCs it is important to rule out high numbers of $\mathrm{CD} 13^{+}$cells as this is a marker for fibroblasts, which are often used as the starting cells in the manufacture of iPSCs.

As the manufacturing process progresses and pluripotent cells are differentiated into the final cell product, some of the most important contaminants are the residual undifferentiated stem cells that could eventually proliferate in transplanted hosts to form teratomas [69]. Tumorgenicity is one of the greatest safety concerns for pluripotent and multipotent cells (Table 4). The delivery of cells with an unlimited ability to renew and the capacity to differentiate into other cell types carries a significant risk that must be addressed [67]. The gold standard test for teratoma formation is to inject the cells into immunodeficient rodents and wait for the formation of a teratoma in the animal [67]. Only a few undifferentiated cells are theoretically needed to form a teratoma in mice, although for testing purposes typically 3-5 million cells are injected into immune-deficient mice [70]. However, this test is costly, time consuming and has animal welfare concerns when used on a wide scale, as identified by the International Stem Cell Initiative [71]. Alternative, more quantifiable methods are needed, such as in vitro assays, including qRT-PCR [72]. 
Initial work with iPSCs included reprogramming the cells using retroviral constructs, which were permanently integrated into the cell genome. This method left great uncertainty concerning the long-term effect of the viral DNA. The residual transgenes could affect the function of the cells, but more importantly posed a potential safety risk to the recipient [68]. More recently, safer, nonintegrating viral particles such as Sendai virus or mRNA reprogramming can transfect cells that are used for clinical programs [72,73]. Regardless of the method used, assessment of residual transgenes must be viewed as a potential impurity.

\section{Multipotent stem cells}

For HPC cord blood, the FDA has provided purity specifications that must be met with respect to number of total nucleated cells, viable nucleated cells and viable CD $34^{+}$cells [3]. It is uncommon for the FDA to set defined purity specifications for a cell therapy, thus for the majority of cellular therapies there is wide variation and uncertainty in which surface marker assays should be employed for multipotent cells. This also hampers the evaluation and quantification of impurities related to 'inactive' or unwanted cell populations. As stated earlier, the International Society for Cellular Therapy considers cellular impurities for MSCs as those cells with surface markers for CD34 $4^{+}$, $\mathrm{CD}^{+} 5^{+}, \mathrm{CD} 11 \mathrm{~b}^{+}, \mathrm{CD} 14^{+}, \mathrm{CD} 19^{+}, \mathrm{CD} 79 \alpha^{+}$. These cells should make up $<2 \%$ of all the cells in the final preparation (Table 4) [56].

Another consideration with respect to multipotent cells is the lack of stability over time, which affects the identity of the cells. In one study, ten serial culture passages without differentiation caused changes in $\mathrm{CD} 45^{+}, \mathrm{CD} 34^{+}$and $\mathrm{CD}^{+} 3^{+}$levels compared with the unpassaged bone marrow-derived HPCs [66]. In addition, there were changes in expression levels of $\mathrm{CD} 98^{+}, \mathrm{CD} 205^{+}$and $\mathrm{CD} 106^{+}$cells, all suggesting a decrease in the stemness and thus purity of the HPCs [66].

Concerns of teratoma formation are not as great with MSCs as with pluripotent cells, due to their limited development potential. In fact, decades of use of MSCs and HPCs in the clinic have found few major health concerns around teratoma formation, yet studies have shown that approximately $10 \%$ of MSC samples contain chromosomal aberrations after expansion [74]. It should be noted that for many MSC therapies there are few long-term follow-up studies and so the postmarket safety data is incomplete [75].

\section{Unipotent cells}

Donor tissue used for unipotent cell transplants will always contain a mixture of cells, often including vascular cells and neurons. The best approach for the manufacturing site is to identify the nontarget cells and determine their percentage in the starting material and the final preparation (Table 4).

Purity is important when manufacturing a CAR-T therapy as it may have an impact on patient outcomes. For CAR-T cell therapies, in addition to the peripheral blood mononuclear cells obtained from the patient during apheresis, the starting sample contains red blood cells, monocytes, platelets and several other blood cells. The T-cell content can be enriched using $\mathrm{CD}^{+} / \mathrm{CD}^{+}$antibodies on bead conjugates [18]. The percentage of the nontarget cells after enhancement has been shown to impact the overall success of the CAR-T manufacturing process [28].

As mentioned previously, endotoxin levels must be below $0.5 \mathrm{EU} / \mathrm{ml}$ for the final product to be released regardless of the cell therapy category [65]. Reports of islet transplants with endotoxins show that the frequency and level of endotoxin contamination declined from 1999 to 2010, but still averaged 7.8 EU per patient from 2007 to 2010 with few or no associated adverse events [76],

\section{Sterility}

According to the FDA, sterility is defined as freedom from viable contaminating microorganisms, as determined by the test requirements specified under 21CFR610.12 [30]. Typically, testing for sterility includes assays for bacterial, viral, fungal and mycoplasma [12,77].

Obviously the more a cell therapy is manipulated during the manufacturing process, the higher the chances for contamination of the product, but even minimally manipulated products can contain contaminants [78]. A large study of over $4000 \mathrm{HPC}$ products found that over $1 \%$ were contaminated, most commonly with Staphylococcus epidermidis [78]. Most of these contaminated products were transplanted into the recipients either by choice or necessity, due to the low yield of cells in the manufacturing process and the dire needs of the patient. Few significant adverse clinical outcomes have been reported [79-81]. Contamination can arise from several different sources such as the initial donor sources or from the manufacturing processes and reagents, including incubators, water baths, lab benches, sinks and human error [81]. 
Table 5. Current sterility assays.

\begin{tabular}{|c|c|c|c|c|}
\hline Characterization & Pluripotent stem cells & Multipotent stem cells & Unipotent cells & Ref. \\
\hline Virus (donor screening) & $\begin{array}{l}\text { Negative: HIV types } 1 \text { \& } 2 \text {, HBV, } \\
\text { HCV, human transmissible } \\
\text { spongiform encephalopathy, } \\
\text { syphilis }\end{array}$ & $\begin{array}{l}\text { Negative: HIV types } 1 \text { \& } 2 \text {, HBV, } \\
\text { HCV, human transmissible } \\
\text { spongiform encephalopathy, } \\
\text { syphilis }\end{array}$ & $\begin{array}{l}\text { Negative: HIV types } 1 \text { \& } 2 \text {, HBV, HCV, } \\
\text { human transmissible spongiform } \\
\text { encephalopathy, syphilis }\end{array}$ & {$[30,48,82]$} \\
\hline Bacteria/fungus & Negative & Negative & Negative & {$[12,77]$} \\
\hline Mycoplasm & Negative & Negative & Negative & {$[12,83,84]$} \\
\hline Karyotype analysis & $46, X X$ or $X Y$ & $46, \mathrm{XX}$ or $\mathrm{XY}$ & Not required & \\
\hline \multicolumn{5}{|c|}{$\begin{array}{l}\text { Sterility assays have a high level of harmonization across cell categories and are comprised of viral screening of the donors and testing of the starting material and end-product } \\
\text { for bacteria, fungi, mycoplasm, teratomas along with karyotype analysis. } \\
\text { HBV: Hepatitis B virus; HCV: Hepatitis C virus. }\end{array}$} \\
\hline
\end{tabular}

\section{Uniform sterility assays}

Sterility testing is the single critical quality classification that does not require separate tests for different cell therapy categories and can be reviewed as a general topic. For all allogeneic cells and tissues, the FDA requires screening of the donors in accordance with good tissue practice guidelines. This includes screening donors for: HIV types 1 and 2, hepatitis B and hepatitis C, human transmissible spongiform encephalopathy and syphilis (Table 5) [30]. However, there are cases when additional tests must be conducted for infections such as vaccinia, sepsis, West Nile Virus, SARS and Zika Virus [30,82]. Donors of leukocyte-rich cells or reproductive cells have additional requirements [30]. Other organizations such as International Stem Cell Banking Initiative Guidance suggest additional tests for Epstein-Barr Virus, cytomegalovirus, papillomavirus, herpes simplex virus and herpes viruses [48]. FDA regulations do not require testing for autologous donors for transmissible agents.

For all cell therapies, in-process sterility tests for bacteria and fungus are the only way to test for microbial levels [77]. Fungi infections are rare, but when they occur, they typically include the candidiasis and aspergillosis families. However, most of the time, these infections come from medical treatments during or after the infusion, such as catheters and other breaks in the skin and are not from the donor tissues [85]. Standard sterility tests require some of the longest incubation periods ( 14 day) and the results are often not known until after the lot has been released and administered to a patient. However, in certain cases the FDA has now cleared several automated systems for rapid sterility testing, such as BacT/ALERT and BACTEC [86].

Studies on allogeneic islet transplants have determined that a clinically significant number of human islet final preparations contain microbial contamination, ranging from 16-66\% depending on the manufacturing site [87-89]. Bacterial contamination of hematopoietic stem cell products is estimated at $4.5 \%$ for peripheral blood progenitor cells and as high as 26\% for bone marrow harvests [90]. Most studies found that microbial contamination had little or no effect on the patient outcome, nor was it associated with local or systemic infections [87-91].

Mycoplasma is a unique member of the bacteria family and must be negative for all cell therapies. Mycoplasma are significantly smaller than other bacteria and can pass through a $0.1 \mu \mathrm{m}$ filter [83]. Without a rigid cell wall, they are resistant to most common antibiotics. Once the mycoplasma enters the cell, it is difficult to kill even with mycoplasma-effective antibiotics [84]. Mycoplasma contamination is surprisingly common in cell culture systems and can have a serious negative impact on the outcome of the therapy, including causing genetic instability, physiological changes and increased viral susceptibility [84]. Mycoplasma are often introduced into the manufacturing process by personnel. For example, more than half of all mycoplasma infections in cell cultures are correlated with the healthy human oropharyngeal tract [84].

\section{Potency}

Potency is a critical attribute of any cell therapy, confirming that the product possesses a biological function that is relevant to treating the clinical indication [31]. The FDA interprets assessment of potency measurements as "used to demonstrate that only product lots that meet defined specifications or acceptance criteria are administered during all phases of clinical investigation and following market approval' [31]. Best practices entail choosing potency assays that are relevant to the expected mechanism of action for the specific indication [12], linking it to the in vivo functions and to clinical efficacy [92]. 
Table 6. Examples of potency assays utilized for select cell therapies.

\begin{tabular}{|c|c|c|c|}
\hline Product & Cellular identity & Current potency assays & Ref. \\
\hline Cord Blood from multiple organizations & HPCs & Total nucleated cells, $\mathrm{CD} 34^{+}$cells and cell viability & [94] \\
\hline Yescarta and Kymriah & CD19+ ${ }^{+}$-cell immunotherapy & Cell viability and CAR expression & {$[95,96]$} \\
\hline $\mathrm{MACl}$ & Chondrocytes & Expression of Hyaline 1 & [97] \\
\hline Gintuit & Keratinocytes and fibroblasts & No known mechanism of action; cytokine assay & [98] \\
\hline Laviv & Postauricular fibroblasts & No known mechanism of action; cell number & [99] \\
\hline Provenge & CD54+ cell immunotherapy & $\begin{array}{l}\text { Expression of CD54 on antigen-presenting cells after } \\
\text { activation }\end{array}$ & [14] \\
\hline
\end{tabular}

Potency assays are unique for each product due to the assumed mechanism of action of the therapy. The table lists the current US FDA-approved cell therapies and their stated potency assays.

CAR: Chimeric antigen receptor; CD: Cluster of differentiation; HPC: Hematopoietic progenitor cells; MACI: Matrix-induced autologous chondrocyte implantation.

Developing reliable assays for cell therapy potency is particularly challenging [93]. Therefore, compared with identity, purity and sterility, potency tests are the least likely to have harmonization or standards set by regulatory agencies. Rather, each product may require a unique potency assay or set of assays [93]. It is not possible to list all of the potential potency assays for the cell therapies currently being tested. However, Table 6 provides a summary of the current potency assays for the FDA-approved cellular therapies. In cases where the mechanism of action for the treatment is unknown, the number of live cells is the surrogate potency assay.

Unfortunately, it is common that in vitro assay results fail to predict the in vivo efficacy even when the mechanism of action is known. It may be that the in vivo microenvironment is essential for the pathway of interest to function correctly. For example, in vitro, glucose-stimulated insulin secretion should predict the outcome of the islet transplant in vivo, but little correlation has been found [93]. Likewise, the in vitro cytotoxicity of T-cells against cancer cells should equate to a relative potency assay that would predict the in vivo response. However, in vitro cytotoxic activity appears to have very little correlation with the in vivo potency for some CAR-T therapies [34].

The FDA has outlined some of the challenges for potency assays for cell therapies in its guidance for industry [31]. These challenges include the inherent variability of the starting materials, the limited lot size for testing, limited stability, a lack of appropriate reference standards, multiple active ingredients and the potential for interference or synergy [31]. In a recent review by the FDA, less than half of the submitted INDs included any assay for bioactivity in their documents [58]. Potency assays are required prior to the start of pivotal registrational clinical trials. While it is suggested that in vitro data on potential potency assays be collected early in the development process, this is often difficult when the mechanism of action is not fully understood or easily measured. Typically, potency assays are not validated prior to initiation of the first phase of clinical development. However, for rare diseases, where the first clinical study has the potential to be the registrational study, it is imperative to develop potency assessments early.

\section{Suggested assay harmonization}

In reviewing characterization assays across cell therapies, one thing that becomes clear is that various regulatory and professional organizations classify assays under different headings, which confuses the field. For example, for allogeneic umbilical cord blood the FDA combines 'purity and potency' tests into one category measuring the total prep viability versus the viability of the target cells [3]. Other groups have combined purity and Identity assays into a single heading [36]. By standardizing the purpose for the tests through the categories of identity, impurity, sterility and potency, simple changes can help to provide a common framework for future studies and data sharing.

As previously described, safety is defined in the CFR as relative freedom from harmful effects to the patient by a product but is not a codified release requirement (21CFR610) [30]. Within the manufacturing process, safety should encompass aspects related to all of the critical quality attributes: identity, purity, sterility and potency. Control of these product quality attributes is a critical part of demonstrating a product's overall safety. Thus, listing safety as a separate critical quality attribute is confusing and should be avoided.

Table 7 provides a suggested single organizational structure when considering the minimal critical characterization attribute assays across cell therapy products. The structure was designed to minimize confusion so that the same assays are classified consistently across cell therapies and provide an outline of the minimum mandatory assays required for critical quality characterization. Of course, additional release tests will be necessary that are specific to each cell therapy. 
Table 7. Suggested organization of characterization assays.

\begin{tabular}{|c|c|}
\hline Critical quality assay categories & Recommended assays \\
\hline \multirow[t]{4}{*}{ Sterility } & Adventitious agent \\
\hline & Bacteria/fungal \\
\hline & Endotoxins \\
\hline & Mycoplasma \\
\hline \multirow[t]{5}{*}{ Identity } & Surface markers of target cells \\
\hline & Molecular markers of target cells \\
\hline & Phenotypic markers of target cells \\
\hline & Karyotyping \\
\hline & Other tests: HLA, ALP levels, genome-wide gene expression patterns \\
\hline \multirow[t]{7}{*}{ Impurity } & Surface markers of nontarget cells \\
\hline & Molecular markers of nontarget cells \\
\hline & Phenotypic markers of nontarget cells \\
\hline & Serum components \\
\hline & Competent vectors and DNA \\
\hline & Teratoma formation \\
\hline & Remaining reagents \\
\hline \multirow[t]{3}{*}{ Potency } & Cell number/dose \\
\hline & Viability \\
\hline & Tests of mechanism of action \\
\hline
\end{tabular}

Changes to the four critical quality characterization categories includes changing purity to impurity to distinguish it from identity tests. Within the four categories we propose a standardized manner of classifying the recommended assays so that they are uniform across cell therapies.

In order to better differentiate identify from purity, we have clarified that identity relates only to characterization of the target cell population, while purity characterizes the nontarget cells and other nonbiological impurities. Thus, we suggest that the category be termed 'Impurity' rather than 'purity' to provide more clarification, a concept graphically reinforced in Figure 2.

One of the most important changes is to classify teratoma formation under the heading of purity of the final product, rather than identity of the starting material. While scientists understand that formation of teratomas are a rigorous test to identify whether cells are pluripotent, the public may question identifying target cells by their ability to form tumors. With respect to the final product, the results of teratoma tests are informative to identify undifferentiated cells, in other words off-target cells. Thus, teratoma tests directly reflect the impurity of the preparation.

Additional changes include the removal of endotoxins from the purity tests. Some groups have omitted endodoxin testing from their required criteria for cell bank release [53], although it is likely done. Others place the testing of endotoxins in the sterility category [100] or in its own category [51], whereas the FDA includes endotoxins as a purity issue or fails to explicitly include endotoxin testing in its guidance [3,32]. We suggest that the measurement of endotoxin levels should be considered a sterility issue, not one of purity. Tests for the presence of bacteria are already described under the sterility category. Since endotoxins are lipopolysaccharides found on the surface of bacteria and are shed when bacteria divide or die, it is reasonable that bacterial and endotoxin assays be placed in the same category. Thus, the new organizational structure places the testing of endotoxins under the sterility heading.

Finally, we have provided a suggestion for the minimal assays necessary to characterize potency. Up to this point, viability assays have not been included in many regulatory documents, because traditionally cell viability has not been listed consistently in any of the four categories. Rather FDA guidance lists viability in an 'other' category, along with cell number [31]. Yet, viability is one of the most important and commonly utilized assays in cell therapy manufacturing. The percentage of live cells certainly is related to the potency of the product and we suggest that viability and cell number or tissue volume be set as minimal potency assays. Additional potency tests would be based on the mechanism of action for the product.

\section{Conclusion}

Until the field of cell therapy matures, critical quality characterization assays must be broad, collect as much information as possible with the smallest sample and be agnostic meaning that there are no preconceived ideas 
about which outcomes will be most relevant. We have attempted to standardize communication about critical quality attributes with a suggested organizational structure. By first comparing the differences in critical quality assays across cell therapy types, the design of a simplified and uniform structure is possible.

\section{Future perspective}

We are in an unprecedented time of growth for an entirely new field of medicine. Not surprisingly, there has been a significant lack of standardization around characterizing the starting material, the manufacturing process and critical criteria for product release of cells. However, the pendulum moved quickly with approval of cancer treatments that combined genetic and cellular therapy technologies. The quick acceptance of anti-cancer immunotherapies required manufacturing procedures that met standards similar to traditional chemical drugs, which brings us to a point where the industry can begin to speak with a more unified vocabulary about common practices. To that end, we offer one approach to facilitate harmonization around critical quality attribute testing. Undoubtedly, the field of cell therapy manufacturing will mature to the quality of chemical drug manufacturing. The length of time required to get to that point, depends on our ability to learn from each other and adapt.

\section{Executive summary}

- While the banking and manufacturing processes for cell therapies has been addressed by some international organization, less attention has been placed on the assays used to characterize the quality of either the starting material or the final product.

- The disparities between organizations and regulatory documents when describing critical quality attribute assays are highlighted.

- A clear definition of the three categories of cell therapies based on the starting cells: pluripotent, multipotent and unipotent is presented.

- Critical quality characterization assays are reviewed for each cell category covering identity, purity, sterility and potency.

- Discrepancies and agreements concerning the organization and types of assays utilized are highlighted.

- A simplified organizational structure was proposed to unify the classification and vocabulary around cell therapy critical quality characterization assays is proposed.

Financial \& competing interests disclosure

All authors are employees of their designated organizations, which work in the stem cell field. Dr. Stehno-Bittel is a partial owner of Likarda, LLC. The authors have no other relevant affiliations or financial involvement with any organization or entity with a financial interest in or financial conflict with the subject matter or materials discussed in the manuscript apart from those disclosed.

No writing assistance was utilized in the production of this manuscript.

\section{Open access}

This work is licensed under the Attribution-NonCommercial-NoDerivatives 4.0 Unported License. To view a copy of this license, visit http://creativecommons.org/licenses/by-nc-nd/4.0/

\section{References}

Papers of special note have been highlighted as: • of interest; $\bullet \bullet$ of considerable interest

1. Aijaz A, Li M, Smith D et al. Biomanufacturing for clinically advanced cell therapies. Nat. Biomed. Eng. 2(6), 362-376 (2018).

2. Cuende N, Rasko J, Koh M, Dominici M, Ikonomou L. Cell, tissue and gene products with marketing authorization in 2018 worldwide. Cytotherapy 20, 1401-1413 (2018).

3. Food and Drug Administration, Center for Biologics Evaluation and Research. Guidance for Industry: biologics license applications for minimally manipulated, unrelated allogeneic palcental/umbilical cord blood intended for hematopoietic and immunologic reconstruction in patients with disorders affecting the hematopoietic system. In: US Department of Health and Human Services. MD, USA, 11-25 (2014).

4. US National Library of Medicine. ClinicalTrials.gov. NIH (2020). https://clinicaltrials.gov/ct2/home

5. Jossen V, Van den Bos C, Eibl R, Eibl D. Manufacturing human mesenchymal stem cells at clinical scale: process and regulatory challenges. Appl. Microbiol. Biotechnol. 102, 3981-3994 (2018).

6. Mizukami A, Swiech K. Mesenchymal stromal cells: from discovery to manufacturing and commercialization. Stem Cells Int. 4083921, $1-13$ (2018). 
7. Pigeau G, Csaszar E, Dulgar-Tulloch A. Commercial scale manufacturing of allogeneic cell therapy. Front. Med. 5, 233 (2018).

8. Fekete N, Beland A, Campbell K, Clark S, Hoesli C. Bags versus flasks: a comparison of cell culture systems for the production of dendritic cell-based immunotherapies. Transfusion 58, 1800-1813 (2018).

9. Schwedhelm I, Zdzieblo D, Appelt-Menzel A et al. Automated real-time monitoring of human pluripotent stem cell aggregation in stirred tank reactors. Sci. Rep. 9, 12297 (2019).

10. Kim JH, Adlerton A, Crook JM et al. A report from a workshop of the International Stem Cell Banking Initiative, held in collaboration of Global Alliance for iPSC Therapies and the Harvard Stem Cell Institute, Boston, 2017. Stem Cells 27, 1130-1135 (2019).

-• Provides summaries of discussion of the latest International Stem Cell Banking Initiative.

11. Sakurai K, Kurtz A, Stacey G, Sheldon M, Fujibuchi W. First proposal for minimum information about a cellular assay for regenerative medicine. Stem Cells Transl. Med. 5, 1345-1361 (2016).

12. Carmen J, Burger S, McCaman M, Rowley J. Developing assays to address identify, potency, purity and safety: cell characterization in cell therapy process development. Regen. Med. 7, 85-100 (2012).

-. Offers an important approach to developing critical quality characterization assays.

13. Food and Drug Administration. Guidance for FDA Reviewers and Sponsors: Content and Review of Chemistry, Manufacturing and Control (CMC) Information for Human Somatic Cell Therapy Investigational New Drug Applications (INDs). In: US Department of Health and Human Services. Center for Biologics Evaluation and Research ed., Office of Communication, Outreach and Development, MD, USA, 1-39 (2008).

- Provides the definitive review of the USFDA's approach to somatic cell therapies.

14. Dendreon Medical Affairs. PROVENGE: summary of product characterization. WA, USA, 1-17 (2019). www.fda.gov/media/78511/download

15. Lui G, David BT, Trawczynski M, Fessler RG. Advances in pluripotent stem cells: history, mechanisms, technologies and applications. Stem Cell Rev. Rep. 16(1), 3-32 (2020).

16. Passweg J, Halter J, Bucher C, et al. Hematopoietic stem cell transplantation: a review and recommendations for follow-up care for the general practitioner. Swiss Med. Wkly 142, w13696 (2012).

17. Food and Drug Administration. Regulatory Considerations for Human Cells, Tissues and Cellular and Tissue-Based Products: Minimal Manipulation and Homologous Use: Guidance for Industry and Food and Drug Administration Staff. In: US Department of Health and Human Services, Center for Biologics Evaluation and Research ed. MD, USA (2017).

- Defines the criteria for minimal manipulation and describes the critical quality assays used for product release testing.

18. Levine B, Miskin J, Wonnacott K, Keir C. Global manufacturing of CAR-T cell therapy. Mol. Ther. Meth. Clin. Dev. 4, 92-101 (2017).

19. Marks P, Witten C, Califf R. Clarifying stem-cell therapy's benefits and risks. N. Engl. J. Med. 276, 1007-1009 (2017).

20. Sipp D, Robey P, Turner L. Clear up this stem-cell mess. Nature 561, 455-457 (2018).

21. Horwitz E, Le Blanc K, Dominici M et al. International Society for Cellular Therapy. Clarification of the nomenclature for MSC: The International Society for Cellular Therapy position statement. Cytotherapy 7, 393-394 (2005).

22. Lukomska B, Stanaszek L, Zuba-Surma E, Legosz P, Sarznska S, Drela K. Challenges and controversies in human mesenchymal stem cell therapy. Stem Cells Int. 9628536 (2019).

23. Gnani D, Crippa S, della Volpe L et al. An early-senescence state in aged mesenchymal stromal cells contributes to hematopoietic stem and progenitor cell clonogenic impairment through the activation of the pro-inflammatory program. Aging Cell 18, 312933 (2019).

24. Yano K, Speidel A, Yamato M. Food and Drug Administration Draft Guidance Documents and the REGROW Act: a litmus test for future changes in human cell- and tissue-based products regulatory policy in the United States? J. Tissue Eng. Regen. Med. 12, 1579-1593 (2018).

25. Bottino R, Knoll M, Knoll C, Bertera S, Trucco M. The future of islet transplantation is now. Front. Med. 5, 1-13 (2018).

26. Schmid C, Labopin M, Nagler A et al. Donor lymphocyte infusion in the treatment of first hematological relapse after allogeneic stem-cell transplantation in adults with acute myeloid leukemia: a retrospective risk factors analysis and comparison with other strategies by the EBMT Acute Leukemia Working Party. J. Clin. Oncol. 25(31), 4938-4945 (2007).

27. Thomson AW, Metes DM, Ezzerlarab MB, Raich-Regue D. Regulatory dendritic cells for human organ transplantation. Transplan. Rev. 33, 130-136 (2019).

28. Kassim S. Toward an integrated model of product characterization for CAR-T cell therapy drug development efforts. Cell Gene Ther. Insights 4, 227-237 (2017).

29. Silverman LI, Flanagan F, Rodrigues-Granrose D, Simpson K, Saxon LH, Foley KT. Identifying and managing sources of variability in cell therapy manufacturing and clinical trials. Reg. Eng. Transl. Med. 5, 354-361 (2019).

30. U.S. Food and Drug Administration. Code of Federal Regulations Title 21: Food and Drugs, Chapter 1 Food and Drug Administration Department of Health and Human Services, Subchapter F - Biologics.

(2019). www.accessdata.fda.gov/scripts/cdrh/cfdocs/cfcfr/CRFSearch.cfm?fr $\mathrm{r}=600.3$ 
31. Food and Drug Administration.Guidance for Industry: potency tests for cellular and gene therapy products. US Department of Health and Human Services, Center for Biologics Evaluation and Research ed, MD, USA (2011). www.fda.gov/media/79856/download

- Comprised of the FDA's guidance for creating and testing potency assays for cellular and gene therapy and includes the acknowledgement of the complexity of the issue.

32. Food and Drug Administration.Guidance for Industry: validation of growth-based rapid microbiological methods for sterility testing of cellular and gene therapy products. US Department of Health and Human Services, Center for Biologics Evaluation and Research ed, MD, USA (2008). www.federalregister.gov/documents/2008/02/11/E8-2398/draft-guidance-for-industry-validation-of-growth-ba sed-rapid-microbiological-methods-for-sterility

33. Lin-Gibson S, Sarkar S, Ito Y. Defining quality attributes to enable measurement assurance for cell therapy products. Cytotherapy 18, 1241-1244 (2016).

34. Milone M, Bhoj V. The pharmacology of T cell therapies. Mol. Ther. Meth. Clin. Dev. 8, 210-221 (2018).

35. Pamies D, Bal-Price A, Simeonov A et al. Good cell culture practice for stem cells and stem-cell-derived models. ALTEX 34, 95-132 (2016).

36. Baghbaderani B, Syama A, Sivapatham R et al. Detailed characterization of human induced pluripotent stem cells manufactured for therapeutic applications. Stem Cell Rev. 12, 394-420 (2016).

37. Rao M, Pei Y, Garcia T et al. Illustrating the potency of current Good Manufacturing Practice-compliant induced pluripotent stem cell lines as a source of multiple cell lineages using standardized protocols. Cytotherapy 20, 861-872 (2018).

38. Trusler O, Huang Z, Goodwin J, Laslett A. Cell surface markers for the identification and study of human naive pluripotent stem cells. Stem Cell Res. 26, 36-43 (2018).

39. Strebinger D, Deluz C, Friman ET, Govindan S, Alber AB, Suter DM. Endogenous fluctuations of OCT4 and SOX2 bias pluripotent cell fate decisions. Mol. Syst. Biol. 15, e9002 (2019).

40. Heurtier V, Owens N, Gonzalez I et al. The molecular logic of Nanog-induced self-renewal in mouse embryonic stem cells. Nat. Comm. 10, 1109 (2019).

41. Majeti R, Park C, Weissman I. Identification of hierarchy of multipotent hematopoietic progenitors in human cord blood. Cell Stem Cell 1, 635-645 (2007).

42. Samsonraj R, Raghunath M, Nurcombe V, Hui J, van Wijnene A, Cool S. Concise review: multifaceted characterization of human mesenchymal stem cells for use in regenerative medicine. Stem Cells Transl. Med. 6, 2173-2185 (2017).

43. Lv FJ, Tuan R, Cheung K, Leung V. Concise review: the surface markers and identity of human mesenchymal stem cells. Stem Cells 32 , 1408-1419 (2014).

44. Castro-Malaspina H, Gay R, Resnick G et al. Characterization of human bone marrow fibroblast colony-forming cells (CFU-F) and their progeny. Blood 56, 289-301 (1980).

45. Bock C, Kisnkinis E, Verstapen G et al. Reference maps of human ES and iPS cell variation enable high-throughput characterization of pluripotent cell lines. Cell 144, 439-452 (2011).

46. Dick J, Bhatia M, Gan O, Kapp U, Wang J. Assay of human stem cells by repopulation of NOD/SCID mice. Stem Cells 15, 199-203 (1997).

47. Henry MP, Hawkins JR, Boyle J, Bridger JM. The genetic health of human pluripotent stem cells: genomic instability and the consequences on nuclear organization. Front. Genet. 9, 623 (2018).

48. International Stem Cell Banking Initiative. Consensus guidance for banking and supply of human embryonic stem cell lines for research purposes. Stem Cell Rev. 5, 301-304 (2009).

49. Stefkova K, Prochazkova J, Pachernik J. Alkaline phosphatase in stem cells. Stem Cells Int. 2015, 1-11 (2015).

50. Huang CY, Liu CL, Ting CY et al. Human iPSC banking: barriers and opportunities. J. Biomed. Sci. 26, 87 (2019).

51. Sullivan S, Stacey G, Akazawa C et al. Quality control guidelines for clinical-grade human induced pluripotent stem cell lines. Regen. Med. 13(7), 859-866 (2018).

52. Dunn K, Palecek S. Engineering scalable manufacturing of high-quality stem cell-derived cardiomyocytes for cardiac tissue repair. Front. Med. 5, 110 (2018).

53. O'Shea O, Steeg R, Chapman C, Mackintosh P, Stacey GN. Development and implementation of large-scale quality control for the European bank for induced pluripotent stem cells. Stem Cell Res. 45, 101773 (2020).

54. Sills E, Takeuchi T, Tanaka N, Neri Q, Palermo G. Identification and isolation of embryonic stem cells in reproductive endocrinology: theoretical protocols for conservation of human embryos derived from in vitro fertilization. Theor. Biol. Med. Model 2, 25 (2005).

55. Liu M, Miller CL, Eaves CJ. Human long-term culture initiating cell assay. Meth. Mol. Biol. 946, 241-256 (2013).

56. Dominici M, Le Blanc K, Mueller I. Minimal criteria for defining multipotent mesenchymal stromal cells. The International Society for Cellular Therapy position statement. Cytotherapy 8, 315-317 (2006).

- Contains the International Society for Cellular Therapy's minimal criteria for characterizing multipotent stromal cells. 
57. Camilleri E, Gustafson M, Dudakovic A et al. Identification and validation of multiple cell surface markers of clinical-grade adipose-derived mesenchymal stromal cells as novel release criteria for good manufacturing practice-compliant production. Stem Cell Res. Ther. 7, 107 (2016).

58. Mendicino M, Bailey A, Wonnacott K, Puri R, Bauer S. MSC-based product characterization for clinical trials: an FDA perspective. Cell Stem Cell 14, 141-145 (2014).

59. Muraglia A, Cancedda R, Quarto R. Clonal mesenchymal progenitors from human bone marrow differentiate in vitro according to a hierarchical model. J. Cell Sci. 113, 1161-1166 (2000).

60. Martinez C, Hofmann T, Marino R, Dominici M, Horwitz E. Human bone marrow mesenchymal stromal cells express the neural ganglioside GD2: a novel surface marker for the identification of MSCs. Blood 109, 4245-4248 (2007).

61. Albrecht C, Tichy B, Numberger S, Hosinert S, Zak L, Aldrian S. Gene expression and cell differentiation in matrix-associated chondrocytes transplantation grafts; a comparative study. Osteoarth. Cart. 19, 1219-1227 (2011).

62. Buchwald P, Bernal A, Echeverri F, Tamayo-Garcia A, Linetsky E, Ricordi C. Fully automated islet cell counter (ICC) for the assessment of islet mass, purity and size distribution by digital image analysis. Cell Transplant. 25, 1747-1761 (2016).

63. Czapla J, Matuszczak S, Kulik K et al. The effect of culture media on large-scale expansion and characteristic of adipose tissue-derived mesenchymal stromal cells. Stem Cell Res. Ther. 10, 325 (2019).

64. Kakudo N, Morimoto N, Ma Y, Kusumoto K. Differences between the proliferative effects of human platelet lysate and fetal bovine serum on human adipose-derived stem cells. Cells 8, 1218 (2019).

65. Liu S, de Castro L, Jin P et al. Manufacturing differences affect human bone marrow stromal cell characteristics and function: comparison of production methods and products from multiple centers. Sci. Rep. 7, 46731 (2017).

66. Moravcikova E, Meyer E, Corselli M, Donnenberg V, Donnenberg A. Proteomic profiling of native unpassaged and culture-expanded mesenchymal stromal cells. Cytometery A 93, 894-904 (2018).

67. Goldring C, Duffy P, Benvenisty N et al. Assessing the safety of stem cell therapeutics. Cell Stem Cell 8, 618-628 (2011).

68. Ramos-Mejia V, Montes R, Bueno C et al. Residual expression of the reprogramming factors prevents differentiation of iPSC generated from human fibroblasts and cord blood CD34+ progenitors. PLoS ONE 7, e35824 (2012).

69. Nagashima T, Shimizu K, Matsumoto R, Honda H. Selective elimination of human induced pluripotent stem cells using medium with high concentration of L-alanine. Sci. Rep. 8, 12427 (2018).

70. Hertze H, Soong P, Wang S, Phillips B, Putte T, Dunn N. Teratoma formation by human embryonic stem cells: evaluation of essential parameters for future safety studies. Stem Cell Res. 2, 198-210 (2009).

71. The International Stem Cell Initiative. Assessment of established techniques to determine developmental and malignant potential of human pluripotent stem cells. Nat. Comm. 9, 1925 (2018).

72. Carcamo-Orive I, Hoffman G, Cundiff P et al. Analysis of transcriptional variability in a large human iPSC library reveals genetic and non-genetic determinants for heterogeneity. Cell Stem Cell 20, 518-532 (2017).

73. Abraham E, Ahmadian BB, Holderness K, Levinson Y, McAfee E. Platforms for manufacturing allogeneic, autologous and iPSC cell therapy products: an industry perspective. Adv. Biochem. Eng. Biotechnol. 165, 323-350 (2018).

74. Nikitina V, Astrelina $\mathrm{T}$, Nugis $\mathrm{V}$ et al. Clonal chromosomal and genomic instability during human multipotent mesenchymal stromal cells long-term culture. PLoS ONE 13, e0192445 (2018).

75. Herberts C, Kwa M, Hermsen H. Risk factors in the development of stem cell therapy. J. Transl. Med. 9, 29 (2011).

76. Balamurugan A, Naziruddin B, Lockridge A et al. Islet product characteristics and factors related to successful human islet transplantation from the Collaborative Islet Transplant Registry (CITR) 1999-2010. Am. J. Transplant. 14, 2595-2606 (2014).

77. Glavez P, Clares B, Bermego M, Hmadcha A, Soria B. Standard requirement of a microbiological quality control program for the manufacture of human mesenchymal stem cells for clinical use. Stem Cells Dev. 23, 1074-1083 (2014).

78. Antoniewicz-Papis J, Lachert E, Rosiek A, Letowska M. Microbial contamination risk in hematopoietic stem cell products: retrospective analysis of 1996-2015 data. Acta Haematol. Pol. 51(1), 29-33 (2020).

79. Nifong T, Ehmann W, Mierski J, Domen R, Rybka W. Favorable outcome after infusion of coagulase-negative staphylococci-contaminated peripheral blood hematopoietic cells for autologous transplantation. Arch. Pathol. Lab. Meth. 127, e19-e21 (2003).

80. Schwella N, Rick O, Heuft $\mathrm{H}$ et al. Bacterial contamination of autologous bone marrow: reinfusion of culture-positive grafts does not result in clinical sequelae during the posttransplantation course. Vox Sang. 74, 88-94 (1998).

81. Webb I, Coral F andersen $\mathrm{J}$ et al. Sources and sequelae of bacterial contamination of hematopoietic stem cell components: implications for the safety of hematotherapy and graft engineering. Transfusion 36, 782-788 (1996).

82. White SL Rawlinson W Boan P et al. Infectious disease transmission in solid organ transplantation: donor evaluation, recipient risk, and outcomes of transmission. Transplant Direct 4, e416 (2018).

83. Wehbe K, Vezzalini M, Cinque G. Detection of mycoplasma in contaminated mammalian cell culture using FTIR microspectroscopy. Anal. Bioanalyt. Chem. 410, 3003-3016 (2018). 
84. Nikfarjam L, Farzaneh P. Prevention and detection of mycoplasma contamination in cell culture. Cell J. 13, 203-212 (2012).

85. Montoro J, Pinana J, Moscardo F, Sanz J. Infectious complications after umbilical cord-blood transplantation from unrelated donors. Mediter. J. Hematol. Infect. Dis. 8, e2016051 (2016).

86. England MR, Stock F, Gebo JET et al. Comprehensive evaluation of compendia USP $<71>$, BacT/Alert Dual-T and Bactec FX for detection of product sterility testing contaminants. J Clin Microbio. 57, e01548-18 (2019).

87. Gala-Lopez B, Kin T, O'Gorman D et al. Microbial contamination of clinical islet transplant preparations is associated with very low risk of infection. Diabetes Technol. Ther. 15, 323-327 (2013).

88. Jolissaint J, Langman L, DeBolt C et al. The impact of bacterial colonization on graft success after total pancreatectomy with autologous islet transplantation: considerations for early definitive surgical intervention. Clin. Trans. 30, 1473-1479 (2016).

89. Berger M, Majumder K, Hodges J et al. Microbial contamination of transplant solutions during pancreatic islet autotransplants is not associated with clinical infection in a pediatric population. Pancreatology 16, 555-562 (2016).

90. Perkins KM, Spoto S, Rankin DA et al. Notes from the field: infections after receipt of bacterially contaminated umbilical cord blood-derived stem cell products for other than hematopoietic or immunologic reconstitution - United States, 2018, Morbidity and Mortality Weekly Report. Center for Disease and Prevention, GA, USA (2018).

91. Meier R andrey D, Sun P et al. Pancreas preservation fluid microbial contamination is associated with poor islet isolation outcomes - a multi-centre cohort study. Transpl. Int. 31, 917-929 (2018).

92. De Wolf C, van de Bovenkamp M, Hoefnagel M. Regulatory perspective on the in vitro potency assays for human $\mathrm{T}$ cells used in anti-tumor immunotherapy. Cytotherapy 20, 601-622 (2018).

93. Eckhard M, Brandhorst D, Winter $\mathrm{D}$ et al. The role of current product release criteria for identification of human islet preparations suitable for clinical transplantation. Transplant. Proc. 36, 1528-1531 (2004).

94. Hematopoietic progenitor cells, cord blood. MD anderson cord blood. 1-21 (2020). www.google.com/search?client=saf ari\&rls=en\&q=h ematopoietic+progenitor+cells $+\mathrm{MD}+$ anderson+pacage\&ie $=\mathrm{UTF}-8 \& \mathrm{zoe}=\mathrm{UTF}-8$

95. Havert M. Summary basis for regulatory action, BLA\# 125643, kite pharma, incorporated (2017). www.google.com/search?client=saf ar $\mathrm{i} \& \mathrm{rl} s=\mathrm{en} \& \mathrm{q}=$ Summary+basis+for+regulatory+action+yescarta\&ie=UTF-8\&oe=UTF-8

96. Food and Drug Administration, Oncologic Drugs Advisory Committee Meeting, FDA Briefing Document. BLA 125646: Tisagenlecleucel, Novartis Pharmaceuticals Corporation (2020). www.fda.gov/media/106081/download

97. Rapko S, Parker A, Mortelliti C, Duguay SJ, Wolfe L. OR15: novel identity and potency quality control assays for autologous chondrocyte implantation. Ortho. Proc. 92-B(Suppl.1), (2018).

98. Lee MH. Summary basis for regulatory action, BLA\# 125400/0, organogenesis, Gintuit (2012). https://regulatorydoctor.us/wp-content/uploads/2015/12/Summary-Basis-for-Regulatory-Action-for-Gintuit.pdf

99. Fibrocell technologies, Inc. LAVIV: full prescribing information (2020). www.fda.gov/media/80838/download

100. Rehakova D, Souralova T, Koutna I. Clinical-grade human pluripotent stem cells for cell therapy: characterization strategy. Int. J. Mol. Sci. 21, 2435 (2020). 